\title{
Pengaruh Kombinasi Perlakuan Air Panas dan Kultur Jaringan terhadap Infeksi Virus pada Bawang Merah
}

\section{Effect of Combination of Hot Water Treatment and Tissue Culture on Virus Infections in Shallot}

\author{
Astri Windia Wulandari ${ }^{1,2 *}$, Sobir ${ }^{1}$, Sri Hendrastuti Hidayat ${ }^{1}$ \\ ${ }^{1}$ Institut Pertanian Bogor, Bogor 16680 \\ ${ }^{2}$ Balai Penelitian Tanaman Sayuran, Bandung 40391
}

\begin{abstract}
ABSTRAK
Sebagian besar petani bawang merah di Indonesia menggunakan umbi sebagai bahan perbanyakan meskipun banyak penyakit diketahui ditularkan melalui umbi. Perlakuan air atau udara panas pada organ aktif seperti biji atau umbi adalah metode yang umum digunakan untuk menghasilkan tanaman bebas virus. Penelitian ini dilakukan untuk mendapatkan umbi bawang merah bebas virus melalui perlakuan air panas dikombinasikan dengan kultur jaringan. Deteksi virus sebelum perlakuan menggunakan Dot immuno binding assay (DIBA) untuk memastikan infeksi genus Potyvirus (Onion yellow dwarf virus/OYDV), Carlavirus (Shallot latent virus/SLV dan Garlic common latent virus/GCLV) dari umbi. Penelitian disusun menggunakan rancangan acak lengkap dengan tiga faktor, yaitu kultivar (Sumenep dan Bima Curut), suhu $\left(45^{\circ} \mathrm{C}, 50{ }^{\circ} \mathrm{C}\right.$, dan suhu kamar), dan waktu pemanasan (15 dan 30 menit). Secara umum, perlakuan air panas yang dikombinasikan dengan kultur jaringan tidak memengaruhi kemampuan tumbuh dan jumlah daun planlet. Berdasarkan deteksi virus menggunakan RT-PCR, suhu $45{ }^{\circ} \mathrm{C}$ selama 15 menit mampu mengeliminasi $100 \%$ Potyvirus dan Carlavirus pada bawang merah 'Bima Curut'; sedangkan pada bawang merah 'Sumenep' perlakuan air panas pada suhu $50{ }^{\circ} \mathrm{C}$ selama 15 menit mampu mengeliminasi 100\% Potyvirus dan 33.33\% Carlavirus.
\end{abstract}

Kata kunci: bebas virus, 'Bima Curut', Carlavirus, Potyvirus, 'Sumenep'

\begin{abstract}
Most shallot farmers in Indonesia use bulbs as their propagative materials despite many diseases were known to be transmitted through bulbs. Heat treatment is a common method used to produce virusfree plants, i.e. using hot water or hot air treatment which is generally applied on the dormant organs such as seeds or bulbs. Research was conducted to get virus free shallot bulbs through hot water treatment combined with tissue culture. Detection of the virus before treatment using Dot immuno binding assay confirmed the infection of Potyvirus (Onion yellow dwarf virus/OYDV), Carlavirus (Shallot latent virus/ SLV and Garlic common latent virus/GCLV) from bulb. The experiment was done using a completely randomized design with three factors, i.e. cultivar (Sumenep and Bima Curut), temperature $\left(45^{\circ} \mathrm{C}, 50^{\circ} \mathrm{C}\right.$, and room temperature), and heating time (15 and $30 \mathrm{~min}$ ). In general, hot water treatment combined with tissue culture did not affect the ability of plantlets to grow and the number of leaf. Based on virus detection using RT-PCR, $100 \%$ elimination of Potyvirus and Carlavirus on cultivar Bima Curut was observed at temperature of $45^{\circ} \mathrm{C}$ for 15 minutes; whereas on cultivar Sumenep hot water treatment at $50{ }^{\circ} \mathrm{C}$ for 15 minutes was able to eliminate $100 \%$ Potyvirus and $33.33 \%$ Carlavirus.
\end{abstract}

Keywords: 'Bima Curut', Carlavirus, Potyvirus, 'Sumenep', virus free

*Alamat penulis korespondensi: Balai Penelitian Tanaman Sayuran. Jalan Tangkuban Parahu No. 517. Lembang - Bandung Barat 40391.

Tel: 022-2786245, Surel: aww_28@yahoo.com 


\section{PENDAHULUAN}

Salah satu penyebab rendahnya produksi bawang merah di Indonesia ialah ketersediaan benih yang berkualitas tinggi. Kualitas benih bawang merah ditentukan antara lain oleh status kesehatan benih. Benih yang berkualitas adalah benih yang bebas patogen termasuk bebas dari infeksi virus. Tanaman bawang merah dapat terinfeksi oleh virus dari genus Potyvirus (Onion yellow dwarf virus/ OYDV, Shallot yellow stripe virus/SYSV, dan Leek yellow stripe virus/LYSV), Carlavirus (Shallot latent virus/SLV dan Garlic common latent virus/GCLV), dan Allexivirus (Shallot mite borne latent virus/MbLV, Gar-V-B, GarV-C, Gar-V-D dan Garlic mosaic virus/GMV) (Fajaro et al. 2001; Shahraeen et al. 2008). Jenis virus yang menginfeksi bawang merah di Indonesia dilaporkan oleh Duriat (1990), Duriat et al. (1990), dan Sutarya et al. (1993) terdiri atas OYDV, LYSV, dan SLV dengan insidensi penyakit berkisar antara 29.75$76.36 \%$.

Virus yang menginfeksi jaringan tanaman akan terus berkembang sehingga dapat memengaruhi kualitas bahan tanaman yang dihasilkan. Salah satu teknik yang dapat mengeliminasi virus dari jaringan umbi bawang merah ialah teknik kultur jaringan (Gunawan 1987). Efisiensi teknik kultur jaringan untuk mengeliminasi virus dapat ditingkatkan dengan kombinasi perlakuan fisik seperti terapi pemanasan dan kimiawi menggunakan senyawa antiviral sintetik. Metode yang umum digunakan untuk menghasilkan tanaman bebas virus, antara lain dengan perlakuan air panas (hot water treatment) dan udara panas (hot air treatment) yang diterapkan pada organ aktif seperti benih atau umbi (Hadidi et al. 1998). Almaarri et al. (2012) melaporkan bahwa perlakuan termoterapi pada suhu sekitar $37 \pm 1{ }^{\circ} \mathrm{C}$ selama 40 hari dapat mengeliminasi Potato virus $Y$ pada kentang 'Binella' dan 'Burren' berturut-turut sebesar $81 \%$ dan $75 \%$.

Upaya mengeliminasi virus dari umbi bawang merah perlu dilakukan karena kebutuhan benih sehat akan terus meningkat seiring dengan target produktivitas bawang merah nasional. Kombinasi teknik kultur jaringan dan perlakuan fisik maupun kimiawi diharapkan dapat menjadi metode yang tepat untuk menghasilkan benih bawang merah bebas virus. Penelitian dilakukan dengan tujuan untuk mempelajari potensi perlakuan air panas dan teknik kultur jaringan dalam menekan infeksi virus pada umbi bawang merah.

\section{BAHAN DAN METODE}

Percobaan ini menggunakan dua kultivar bawang merah, yaitu 'Sumenep' yang berasal dari daerah Pacet, Bandung, Jawa Barat dan 'Bima Curut' dari Brebes, Jawa Tengah dengan umur benih sekitar 60 sampai 80 hari setelah panen. Kegiatan diawali dengan mengenali kedua kultivar umbi bawang merah dari karakter morfologinya. Selanjutnya mendeteksi virus yang ada pada umbi melalui daun tunasnya. Percobaan dilakukan menggunakan planlet bawang merah dari dua kultivar umbi yang disediakan melalui proses kultur jaringan. Proses perbanyakan planlet diawali dengan pemberian perlakuan panas pada umbi bawang merah dan perbanyakan eksplan melalui umbinya.

\section{Pengamatan Karakter Kultivar Bawang Merah}

Dua kultivar bawang merah ('Sumenep' dan 'Bima Curut') dianalisis karakternya. Sebanyak 10 umbi bawang merah diukur diameter umbi, jumlah lapisan pada umbi, dan kekerasan umbinya.

\section{Deteksi Virus Bawang Merah}

Sebanyak 15 umbi per kultivar bawang merah ditanam pada medium tanah dan pupuk kandang steril (1:1). Setelah tanaman berumur 30 hari, daun yang tumbuh dipotong. Setiap kultivar diambil sebanyak $0.1 \mathrm{~g}$. Virus di dalam daun bawang merah dideteksi menggunakan metoda dot immunobinding assay (DIBA) (Anggraini dan Hidayat 2014) dengan duplo.

Target virus pada tahap deteksi terdiri atas OYDV, SLV, dan GCLV. Jaringan tanaman dilumatkan dalam tris buffer saline (TBS) 
[Tris $\mathrm{HCl} 0.02 \mathrm{M}, \mathrm{NaCl} 0.5 \mathrm{M} \mathrm{pH} 7.5$ ] dengan konsentrasi 1:20 (b/v). Cairan perasan daun diteteskan pada membran nitroselulosa (Biorad) dan dibiarkan pada suhu ruang selama 3 menit. Membran kemudian direndam dalam larutan blocking non fat milk (50 mL TBS ditambah 2\% Triton X-100 dan 2\% skim milk) selama 1 jam sambil digoyang pada multi shaker EYELAMMS dengan kecepatan $50 \mathrm{rpm}$ pada suhu ruang. Membran selanjutnya dicuci 5 kali masing-masing selama 5 menit dalam $\mathrm{dH}_{2} \mathrm{O}$ sambil digoyang dengan kecepatan $100 \mathrm{rpm}$, kemudian direndam dalam $20 \mathrm{~mL}$ TBS yang mengandung $20 \mathrm{~mL}$ antibodi pertama OYDV/SLV/GCLV ditambah non fat milk dengan konsentrasi akhir $2 \%$ dan diinkubasi selama satu malam pada suhu $4{ }^{\circ} \mathrm{C}$. Membran kemudian dicuci sebanyak lima kali masing-masing dalam $1 \times$ tris buffer saline tween dengan $0.05 \%$ Tween 20 (TBST) selama 5 menit sambil digoyang dengan kecepatan $100 \mathrm{rpm}$, kemudian direndam dalam $20 \mathrm{~mL}$ TBS yang mengandung konjugat (antibodi kedua) sebanyak $40 \mathrm{~mL}$ untuk OYDV/SLV dan $20 \mathrm{~mL}$ untuk GCLV ditambah non fat milk dengan konsentrasi akhir 2\%. Membran diinkubasi selama 60 menit sambil digoyang dengan kecepatan $50 \mathrm{rpm}$, kemudian dicuci kembali dalam TBST sambil digoyang dengan kecepatan 100 rpm. Khusus untuk deteksi SLV, membran selanjutnya direndam dalam $20 \mathrm{~mL}$ TBS yang mengandung $20 \mathrm{~mL}$ antibodi ketiga ditambah non fat milk dengan konsentrasi akhir $2 \%$, kemudian diinkubasi selama 60 menit sambil digoyang dengan kecepatan $50 \mathrm{rpm}$, selanjutnya dicuci kembali dengan TBST.

Tahap terakhir, membran direndam selama 5 menit dalam $10 \mathrm{~mL}$ bufer AP (Tris-HCl $0.1 \mathrm{M}$, $\mathrm{NaCl} 0.1 \mathrm{M}, \mathrm{MgCl}_{2} 5 \mathrm{mM}$ dan air) yang mengandung 1 tablet nitro blue tetrazolium dan bromochloroindolil phosphate (NBT+BCIP). Bila reaksi positif akan terjadi perubahan warna membran menjadi ungu pada tempat cairan tanaman diteteskan yang menunjukkan bahwa sampel yang diuji terinfeksi virus dan reaksi dapat dihentikan dengan merendam membran dalam $\mathrm{dH}_{2} \mathrm{O}$.

\section{Kultur Jaringan untuk Menyediakan Planlet Bebas Virus}

Umbi bawang merah 'Sumenep' dan 'Bima Curut' yang diketahui positif terinfeksi OYDV, SLV dan GCLV digunakan untuk menghasilkan planlet bebas virus. Sebanyak 30 umbi dimasukkan ke dalam kantung jala plastik, kemudian direndam dalam penangas air pada suhu dan lama waktu tertentu sesuai perlakuan, yakni suhu $45{ }^{\circ} \mathrm{C}$ atau $50{ }^{\circ} \mathrm{C}$ dan masing-masing suhu selama 15 atau 30 menit. Umbi yang sudah diberi perlakuan air panas kemudian dikeringanginkan dan digunakan untuk kultur jaringan.

Propagasi tanaman secara in vitro dilakukan di Laboratorium Kultur Jaringan, Pusat Kajian Hortikultura Tropika, IPB. Umbi bawang merah sebagai bahan eksplan yang telah diberi perlakuan panas, dikupas kemudian dicuci dengan larutan deterjen. Umbi direndam di dalam fungisida dengan bahan aktif Streptomisin sulfat dan Benomyl $1 \mathrm{~g} \mathrm{~L}^{-1}$ selama $24 \mathrm{jam}$, lalu bilas dengan air steril sebanyak 2-3 kali.

Selanjutnya sterilisasi dilakukan di laminar air flow cabinet, umbi bawang merah direndam di dalam larutan kloroks $30 \%$ selama 30 menit, lalu dibilas dengan air steril sebanyak 2-3 kali. Selanjutnya lapisan umbi dikupas kembali sampai diperoleh lapisan berwarna putih, lalu direndam dalam kloroks $20 \%$ selama 20 menit, kemudian dibilas dengan air steril sebanyak 2-3 kali. Lapisan dikupas lagi sampai diperoleh bagian yang paling dalam (meristem tip) dan direndam dalam kloroks $10 \%$ selama 10 menit kemudian dibilas dengan air steril sebanyak 2-3 kali.

Eksplan direndam dalam povidone iodine pekat selama 10 menit, selanjutnya ditanam pada medium MS (Murashige dan Skoog 1962) yang dimodifikasi dengan penambahan 30 g gula. Setiap botol ditanami dua eksplan yang selanjutnya diinkubasi di ruang kultur bersuhu $20-22^{\circ} \mathrm{C}$, dengan lama pencahayaan $16 \mathrm{jam}$ terang dan 8 jam gelap (Budiono 2004). Medium perbanyakan menggunakan medium MS ditambah zat pengatur tumbuh N6-(2-Isopentenyl)adenine (2ip) $2 \mathrm{ppm} \mathrm{L}^{-1}$ 


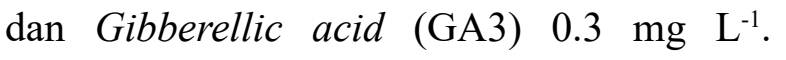
Selanjutnya pertumbuhan planlet diamati.

Penelitian disusun dalam rancangan acak lengkap faktorial dengan 3 faktor. Faktor pertama ialah kultivar bawang merah dengan dua taraf, yaitu 'Bima Curut' dan 'Sumenep'. Faktor kedua ialah suhu pemanasan dengan tiga taraf, yaitu $45^{\circ} \mathrm{C}, 50^{\circ} \mathrm{C}$ dan suhu ruang (kontrol). Faktor ketiga ialah waktu pemanasan dengan dua taraf, yaitu 15 dan 30 menit. Masing-masing ulangan terdiri atas enam botol dan diulang tiga kali.

Pengamatan dilakukan terhadap insidensi virus, daya tumbuh eksplan dan jumlah daun. Insidensi virus dikonfirmasi dengan metode RT-PCR (reverse transcription-polymerase chain reaction). Data dianalisis menggunakan program SAS v9. Jika terdapat perbedaan nyata antar perlakuan, maka dilakukan uji Tukey pada taraf nyata $5 \%$.

\section{Deteksi Insidensi Virus pada Planlet Menggunakan Metode RT-PCR}

Planlet hasil kultur jaringan dideteksi dengan metode RT-PCR digunakan untuk memastikan bahwa planlet sudah bebas virus. Ekstraksi RNA dilakukan mengikuti metode cetyl trimethyl ammonium bromide (CTAB) (Doyle \& Doyle 1990). Produk ekstraksi RNA total digunakan sebagai templat untuk sintesis cDNA. Sintesis cDNA terjadi melalui proses transkripsi balik RNA. Reaksi dibuat dalam tabung mikro dengan total volume $10 \mathrm{~mL}$ yang mengandung $2 \mathrm{~mL}$ bufer RT, $0.50 \mathrm{~mL}$ $10 \mathrm{mM}$ dNTP (deoksiribonukleotida triphosphat), $\quad 0.35 \quad \mathrm{~mL} \quad 50 \quad \mathrm{mM} \quad$ DTT (dithiothreitol), $0.35 \mathrm{~mL}$ RNAse Inhibitor, $0.35 \mathrm{~mL}$ MMuLV (Moloney Murine Leukimia

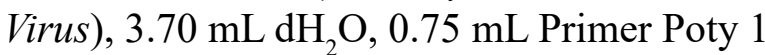

\section{(5'-GGATCCCGGGTTTTTTTTTTTTT} TTTTV-3') dan $2 \mathrm{~mL}$ RNA total. Sintesis cDNA dilakukan pada suhu $65{ }^{\circ} \mathrm{C}$ selama 2 menit, kemudian tabung mikro direndam dalam es, selanjutnya diinkubasi pada suhu $37{ }^{\circ} \mathrm{C}$ selama 60 menit, dan terakhir pada suhu $70{ }^{\circ} \mathrm{C}$ selama 2 menit. Produk RTPCR selanjutnya digunakan untuk tahapan amplifikasi PCR. Reaksi pembanding kontrol positif digunakan cDNA dari tanaman sakit.

Program amplifikasi sebanyak 1 siklus pada $95{ }^{\circ} \mathrm{C}$ selama 1 menit, selanjutnya 35 siklus dengan tahapan denaturasi pada $94{ }^{\circ} \mathrm{C}$ selama 20 detik, aneling pada $56^{\circ} \mathrm{C}$ selama 1 menit, dan sintesis pada $72{ }^{\circ} \mathrm{C}$ selama 1 menit, kemudian khusus untuk siklus terakhir ditambah tahapan sintesis $72^{\circ} \mathrm{C}$ selama 3 menit. Amplifikasi DNA target masing-masing virus (Tabel 1) dilakukan menggunakan mesin Veritiâ Thermal Cycler (Applied Biosystem) dengan kondisi reaksi yang spesifik.

DNA hasil amplifikasi divisualisasi dengan elektroforesis pada tegangan 50 Volt selama 50 menit menggunakan 1\% gel agarosa yang dilarutkan dalam bufer $0.5 \mathrm{x}$ Tris-Borate EDTA (TBE). Gel agarosa kemudian direndam dalam larutan etidium bromida selama 15 menit, dan dilanjutkan dengan pengamatan di bawah UV transilluminator. Penanda ukuran DNA yang digunakan ialah $1 \mathrm{~kb}$ DNA Ladder (Thermo). Infeksi virus pada planlet dideteksi dengan primer universal Potyvirus dan Carlavirus. Pita spesifik Potyvirus berukuran $750 \mathrm{pb}$ berhasil diamplifikasi dari bawang merah 'Bima Curut' dan 'Sumenep'. Pita spesifik Carlavirus berukuran 716 pb berhasil diamplifikasi dari bawang merah 'Bima Curut' dan 'Sumenep'.

Tabel 1 Primer yang digunakan untuk amplifikasi virus bawang merah menggunakan metode PCR

\begin{tabular}{|c|c|c|c|}
\hline Virus target & $\begin{array}{l}\text { Pasangan primer } \\
\left(5, \ldots \ldots . . .33^{\prime}\right)\end{array}$ & $\begin{array}{c}\text { Ukuran DNA } \\
\text { target }(\mathrm{pb})\end{array}$ & $\begin{array}{l}\text { Sumber } \\
\text { pustaka }\end{array}$ \\
\hline $\begin{array}{l}\text { Potyvirus } \\
\text { (U341) }\end{array}$ & $\begin{array}{l}\text { R: GGATCCCGGGTTTTTTTTTTTTTTTTTV } \\
\mathrm{F}: \text { CCGGAATTCATGRTITGGTGYATIGAIAAYGG }\end{array}$ & $600-850$ & $\begin{array}{l}\text { (Langeveld } \\
\text { et al. 1991) }\end{array}$ \\
\hline $\begin{array}{l}\text { Carlavirus } \\
\text { (Alcar) }\end{array}$ & $\begin{array}{l}\mathrm{R}: \text { GGATCCCGGGTTTTTTTTTTTTTTTTTV } \\
\mathrm{F}: \text { TGCTGCYTTTGATACYTTCGAT }\end{array}$ & 715 & $\begin{array}{l}\text { (Gambley } \\
\text { 2012) }\end{array}$ \\
\hline $\begin{array}{l}\text { Allexivirus } \\
(\mathrm{PGV3t})\end{array}$ & $\begin{array}{l}\text { R : GGATCCCGGGTTTTTTTTTTTTTTTTTV } \\
\text { F : TGGNCNTGCTACCACAANGG }\end{array}$ & 950 & $\begin{array}{l}\text { (Chen et al. } \\
\text { 2004) }\end{array}$ \\
\hline
\end{tabular}




\section{HASIL}

Tiga karakter morfologi umbi yang diukur menunjukkan bahwa bawang merah 'Sumenep' dan 'Bima Curut' mempunyai karakter yang berbeda nyata (Tabel 2). Kultivar Sumenep mempunyai diameter lebih besar dibandingkan dengan kultivar Bima Curut; demikian pula jumlah lapisan pada kultivar Sumenep lebih banyak dibandingkan dengan kultivar Bima Curut. Nilai kekerasan umbi kultivar Sumenep lebih rendah dibandingkan dengan kultivar Bima Curut yang menunjukkan bahwa umbi kultivar Sumenep lebih lunak dibandingkan dengan kultivar Bima Curut. Berdasarkan hasil uji serologi dengan metode DIBA, infeksi virus ditemukan lebih tinggi pada kultivar Sumenep dibandingan dengan pada kultivar Bima Curut. Infeksi OYDV, SLV dan GCLV mencapai $86.67 \%$ sampai $100 \%$ pada bawang merah 'Sumenep' dan 'Bima Curut' (Tabel 3).

Pengaruh perlakuan suhu dan waktu pemanasan terhadap pertumbuhan eksplan diukur berdasarkan daya tumbuh dan jumlah daun eksplan. Kombinasi kultivar, suhu dan waktu pemanasan tidak berpengaruh terhadap daya tumbuh eksplan. Kombinasi kultivar dengan suhu pemanasan berpengaruh nyata terhadap daya tumbuh eksplan dan kombinasi kultivar dengan waktu pemanasan berpengaruh nyata terhadap daya tumbuh eksplan pada 1118 HST (Tabel 4).
Perlakuan suhu pemanasan berpengaruh nyata terhadap daya tumbuh eksplan pada 11-18 HST, sementara waktu pemanasan berpengaruh nyata terhadap daya tumbuh eksplan pada 18 HST. Daya tumbuh eksplan tertinggi terjadi pada kultivar Bima Curut.

Jumlah daun berbeda nyata lebih tinggi kultivar Sumenep dibandingkan dengan kultvar Bima Curut pada 28 HST. Perlakuan suhu pemanasan berpengaruh nyata terhadap jumlah daun, sementara waktu pemanasan tidak berpengaruh terhadap jumlah daun. Kombinasi kultivar dengan suhu pemanasan berpengaruh nyata terhadap jumlah daun berturut-turut pada 21 HST dan 28 HST. Kombinasi kultivar dengan waktu pemanasan berbeda nyata terhadap jumlah daun pada 21-28 HST, sedangkan kombinasi kultivar, suhu dan waktu pemanasan berpengaruh nyata terhadap jumlah daun pada 28 HST (Tabel 4).

Infeksi virus pada plantlet setelah perlakuan pemanasan dideteksi dengan metode RT-PCR (Tabel 5). Insidensi virus pada kultivar Sumenep cenderung lebih tinggi dibandingkan dengan pada kultivar Bima Curut. Perlakuan suhu $45{ }^{\circ} \mathrm{C}$ selama 15 menit pada kultivar Bima Curut dapat menekan insidensi Potyvirus dan Carlavirus sampai $100 \%$. Perlakuan suhu $50{ }^{\circ} \mathrm{C}$ selama 15 menit pada kultivar Sumenep dapat menekan Potyvirus sampai 100\% (Tabel 5). Allexivirus tidak ditemukan pada semua

Tabel 2 Morfologi umbi bawang merah kultivar Sumenep dan Bima Curut

\begin{tabular}{lccc}
\hline \multirow{2}{*}{ Parameter } & \multicolumn{2}{c}{ Kultivar } & \multirow{2}{*}{ Hasil uji T* } \\
\cline { 2 - 3 } & Sumenep & Bima Curut & \\
\hline Diameter umbi $(\mathrm{mm})$ & 17.93 & 15.19 & Positif \\
Jumlah lapis & 3.3 & 2.2 & Positif \\
Kekerasan umbi (mm/152 g. 5 detik) & 1.32 & 2.10 & Negatif \\
\hline
\end{tabular}

*Nilai t hitung positif = ada perbedaan bermakna apabila $t$ hitung $>t$ tabel; Nilai $t$ hitung negatif $=$ ada perbedaan bermakna apabila $t$ hitung $<\mathrm{t}$ tabel

Tabel 3 Rata-rata infeksi virus pada daun bawang merah berumur 30 hari setelah tanam berdasarkan hasil deteksi dengan metode DIBA

\begin{tabular}{lccc}
\hline \multirow{2}{*}{ Kultivar } & \multicolumn{3}{c}{ Jumlah sampel terinfeksi/jumlah sampel yang diuji (\%) } \\
\cline { 2 - 4 } & OYDV & SLV & GCLV \\
\hline Bima Curut & $15 / 15(100)$ & $15 / 15(100)$ & $13 / 15(86.67)$ \\
Sumenep & $15 / 15(100)$ & $15 / 15(100)$ & $15 / 15(100)$ \\
\hline
\end{tabular}


Tabel 4 Daya tumbuh dan jumlah daun eksplan bawang merah 'Bima Curut' dan 'Sumenep'

\begin{tabular}{|c|c|c|c|c|c|}
\hline \multirow{2}{*}{ Perlakuan } & \multicolumn{3}{|c|}{ Daya tumbuh eksplan (\%) } & \multicolumn{2}{|c|}{ Jumlah daun } \\
\hline & $11 \mathrm{HST}^{*}$ & $18 \mathrm{HST}$ & $26 \mathrm{HST}$ & $21 \mathrm{HST}$ & $28 \mathrm{HST}$ \\
\hline \multicolumn{6}{|l|}{ Kultivar } \\
\hline Bima Curut (K1) & $82.41 \mathrm{a}^{* *}$ & $85.19 \mathrm{a}$ & $89.82 \mathrm{a}$ & $1.09 \mathrm{a}$ & $1.35 \mathrm{~b}$ \\
\hline Sumenep (K2) & $54.63 \mathrm{~b}$ & $59.26 \mathrm{~b}$ & $76.85 \mathrm{~b}$ & $1.43 \mathrm{a}$ & $1.81 \mathrm{a}$ \\
\hline \multicolumn{6}{|l|}{ Suhu pemanasan : } \\
\hline $45^{\circ} \mathrm{C}(\mathrm{S} 1)$ & $59.73 \mathrm{~b}$ & $59.73 \mathrm{~b}$ & $81.95 \mathrm{a}$ & $0.99 \mathrm{~b}$ & $1.32 \mathrm{~b}$ \\
\hline $50^{\circ} \mathrm{C}(\mathrm{S} 2)$ & $62.50 \mathrm{ab}$ & $65.28 \mathrm{~b}$ & $84.72 \mathrm{a}$ & $0.94 \mathrm{~b}$ & $1.28 \mathrm{~b}$ \\
\hline Suhu ruang (S3) & $83.33 \mathrm{a}$ & $91.67 \mathrm{a}$ & $83.34 \mathrm{a}$ & $1.86 \mathrm{a}$ & $2.14 \mathrm{a}$ \\
\hline \multicolumn{6}{|l|}{ Waktu pemanasan } \\
\hline 15 menit (W1) & $62.96 \mathrm{a}$ & $64.82 \mathrm{~b}$ & $85.19 \mathrm{a}$ & $1.17 \mathrm{a}$ & $1.43 \mathrm{a}$ \\
\hline 30 menit (W2) & $74.07 \mathrm{a}$ & $79.63 a$ & $81.48 \mathrm{a}$ & $1.36 \mathrm{a}$ & $1.73 \mathrm{a}$ \\
\hline \multicolumn{6}{|l|}{ Interaksi : } \\
\hline \multicolumn{6}{|l|}{ Kultivar x Suhu } \\
\hline $\mathrm{K} 1 \mathrm{~S} 1$ & $94.45 \mathrm{a}$ & $94.45 \mathrm{a}$ & $94.45 \mathrm{a}$ & $1.42 \mathrm{ab}$ & $1.42 \mathrm{~b}$ \\
\hline $\mathrm{K} 1 \mathrm{~S} 2$ & $69.45 \mathrm{ab}$ & $77.78 \mathrm{a}$ & $86.12 \mathrm{ab}$ & $0.80 \mathrm{~b}$ & $1.19 \mathrm{~b}$ \\
\hline $\mathrm{K} 1 \mathrm{~S} 3$ & $83.34 \mathrm{a}$ & $83.34 \mathrm{a}$ & $88.89 \mathrm{ab}$ & $1.06 \mathrm{~b}$ & $1.44 \mathrm{~b}$ \\
\hline $\mathrm{K} 2 \mathrm{~S} 1$ & $25.01 \mathrm{~b}$ & $25.01 \mathrm{~b}$ & $69.45 \mathrm{~b}$ & $0.56 \mathrm{~b}$ & $1.22 \mathrm{~b}$ \\
\hline $\mathrm{K} 2 \mathrm{~S} 2$ & $55.55 \mathrm{ab}$ & $52.78 \mathrm{ab}$ & $83.33 \mathrm{ab}$ & $1.08 \mathrm{~b}$ & $1.36 \mathrm{~b}$ \\
\hline $\mathrm{K} 2 \mathrm{~S} 3$ & $83.32 \mathrm{a}$ & $100.00 \mathrm{a}$ & $77.78 \mathrm{ab}$ & $2.67 \mathrm{a}$ & $2.83 \mathrm{a}$ \\
\hline \multicolumn{6}{|l|}{ Kultivar x Waktu } \\
\hline $\mathrm{K} 1 \mathrm{~S} 1$ & $85.19 \mathrm{a}$ & $85.19 \mathrm{a}$ & $90.74 \mathrm{a}$ & $1.20 \mathrm{a}$ & $1.55 \mathrm{a}$ \\
\hline $\mathrm{K} 1 \mathrm{~S} 2$ & $79.63 \mathrm{a}$ & $85.19 \mathrm{a}$ & $88.89 \mathrm{a}$ & $0.98 \mathrm{~b}$ & $1.15 \mathrm{~b}$ \\
\hline $\mathrm{K} 2 \mathrm{~S} 1$ & $40.74 \mathrm{ab}$ & $44.44 \mathrm{ab}$ & $79.63 \mathrm{a}$ & $1.13 \mathrm{a}$ & $1.29 \mathrm{ab}$ \\
\hline $\mathrm{K} 2 \mathrm{~S} 2$ & $68.52 \mathrm{a}$ & $74.08 \mathrm{a}$ & $74.07 \mathrm{a}$ & $1.74 \mathrm{a}$ & $2.32 \mathrm{a}$ \\
\hline \multicolumn{6}{|c|}{ Kultivar x Suhu x Waktu } \\
\hline K1S1W1 & $94.45 \mathrm{a}$ & $94.45 \mathrm{a}$ & $94.45 \mathrm{a}$ & $1.56 \mathrm{a}$ & $1.44 \mathrm{ab}$ \\
\hline K1S1W2 & $94.45 \mathrm{a}$ & $94.45 \mathrm{a}$ & $94.45 \mathrm{a}$ & $1.28 \mathrm{a}$ & $1.39 \mathrm{ab}$ \\
\hline $\mathrm{K} 1 \mathrm{~S} 2 \mathrm{~W} 1$ & $77.78 \mathrm{a}$ & $77.78 \mathrm{a}$ & $88.89 \mathrm{a}$ & $1.00 \mathrm{a}$ & $1.78 \mathrm{ab}$ \\
\hline K1S2W2 & $61.12 \mathrm{a}$ & $77.78 \mathrm{a}$ & $83.34 \mathrm{a}$ & $0.61 \mathrm{a}$ & $0.61 \mathrm{~b}$ \\
\hline K1S3W1 & $83.34 \mathrm{a}$ & $83.34 \mathrm{a}$ & $88.89 \mathrm{a}$ & $1.06 \mathrm{a}$ & $1.44 \mathrm{ab}$ \\
\hline K1S3W2 & $83.34 \mathrm{a}$ & $83.34 \mathrm{a}$ & $88.89 \mathrm{a}$ & $1.06 \mathrm{a}$ & $1.44 \mathrm{ab}$ \\
\hline $\mathrm{K} 2 \mathrm{~S} 1 \mathrm{~W} 1$ & $5.56 \mathrm{a}$ & $5.56 \mathrm{a}$ & $72.22 \mathrm{a}$ & $0.22 \mathrm{a}$ & $0.33 \mathrm{~b}$ \\
\hline $\mathrm{K} 2 \mathrm{~S} 1 \mathrm{~W} 2$ & $44.46 \mathrm{a}$ & $44.46 \mathrm{a}$ & $66.67 \mathrm{a}$ & $0.89 \mathrm{a}$ & $2.11 \mathrm{ab}$ \\
\hline $\mathrm{K} 2 \mathrm{~S} 2 \mathrm{~W} 1$ & $33.34 \mathrm{a}$ & $27.78 \mathrm{a}$ & $88.89 \mathrm{a}$ & $0.50 \mathrm{a}$ & $0.72 \mathrm{~b}$ \\
\hline $\mathrm{K} 2 \mathrm{~S} 2 \mathrm{~W} 2$ & $77.77 \mathrm{a}$ & $77.78 \mathrm{a}$ & $77.78 \mathrm{a}$ & $1.67 \mathrm{a}$ & $2.00 \mathrm{ab}$ \\
\hline $\mathrm{K} 2 \mathrm{~S} 3 \mathrm{~W} 1$ & $83.32 \mathrm{a}$ & $100.00 \mathrm{a}$ & $77.78 \mathrm{a}$ & $2.67 \mathrm{a}$ & $2.83 \mathrm{a}$ \\
\hline $\mathrm{K} 2 \mathrm{~S} 3 \mathrm{~W} 2$ & $83.32 \mathrm{a}$ & $100.00 \mathrm{a}$ & $77.78 \mathrm{a}$ & $2.67 \mathrm{a}$ & $2.83 \mathrm{a}$ \\
\hline Koefisien keragaman & 32.44 & 26.37 & 10.5 & 42.31 & 33.1 \\
\hline
\end{tabular}

*HST, hari setelah tanam

**Angka yang diikuti huruf yang sama pada kolom yang sama tidak berbeda nyata berdasarkan uji BNJ taraf 5\%

sampel diduga karena tidak ada infeksi virus tersebut pada tanaman dan umbi bawang merah di lapangan. Perbedaan respons antarkultivar terhadap suhu dan waktu pemanasan dapat dipengaruhi oleh ukuran umbi, jumlah lapisan, dan kekerasan umbi.

\section{PEMBAHASAN}

Hasil penelitian mengkonfirmasi bahwa bawang merah 'Bima Curut' dan 'Sumenep' terinfeksi berbagai jenis virus, yaitu OYDV, SLV dan GCLV. Dilaporkan sebelumnya 
Tabel 5 Insidensi infeksi virus pada plantlet bawang merah setelah kombinasi perlakuan pemanasan dan kultur jaringan berdasarkan hasil deteksi dengan metode RT-PCR

\begin{tabular}{lcccc}
\hline \multirow{2}{*}{ Kultivar } & $\begin{array}{c}\text { Perlakuan pemanasan } \\
(\text { suhu; waktu) }\end{array}$ & \multicolumn{3}{c}{ Insidensi infeksi virus* (\%) } \\
\cline { 3 - 5 } & $45^{\circ} \mathrm{C} ; 15^{\prime}$ & $0 / 3(0)$ & $0 / 3(0)$ & $0 / 3(0)$ \\
& $45^{\circ} \mathrm{C} ; 30^{\prime}$ & $1 / 3(33.33)$ & $0 / 3(0)$ & $0 / 3(0)$ \\
& $50^{\circ} \mathrm{C} ; 15^{\prime}$ & $1 / 3(33.33)$ & $1 / 3(33.33)$ & $0 / 3(0)$ \\
& $50^{\circ} \mathrm{C} ; 30^{\prime}$ & $0 / 3(0)$ & $1 / 3(33.33)$ & $0 / 3(0)$ \\
& $\mathrm{Kontrol}$ & $1 / 3(33.33)$ & $2 / 3(66.67)$ & $0 / 3(0)$ \\
\hline Sumenep & $45^{\circ} \mathrm{C} ; 15^{\prime}$ & $1 / 1(100)$ & $1 / 1(100)$ & $0 / 1(0)$ \\
& $45^{\circ} \mathrm{C} ; 30$ & $1 / 3(33.33)$ & $1 / 3(33.33)$ & $0 / 3(0)$ \\
& $50^{\circ} \mathrm{C} ; 15^{\prime}$ & $0 / 3(0)$ & $2 / 3(66.67)$ & $0 / 3(0)$ \\
& $50^{\circ} \mathrm{C} ; 30^{\prime}$ & $2 / 3(66.67)$ & $3 / 3(100)$ & $0 / 3(0)$ \\
& $\mathrm{Kontrol}$ & $0 / 3(0)$ & $3 / 3(100)$ & $0 / 3(0)$ \\
\hline
\end{tabular}

*Insidensi infeksi virus merupakan nisbah antara jumlah sampel dengan reaksi positif pada hasil deteksi dengan jumlah total sampel yang diuji.

bahwa beberapa jenis virus berhasil dideteksi dari satu umbi bawang merah. Infeksi kompleks beberapa virus tersebut dapat menyebabkan keparahan penyakit yang lebih besar dibandingkan bila tanaman hanya terinfeksi satu jenis virus (Wulandari et al. 2015). Gunaeni et al. (2011) melaporkan adanya infeksi OYDV, SYSV, dan gabungan OYDV dan SYSV pada bawang merah berturut-turut sebesar $85 \%, 95 \%$, dan $85 \%$.

Kombinasi perlakuan pemanasan dan kultur jaringan berpotensi untuk menekan infeksi beberapa jenis virus dengan suhu dan waktu pemanasan tertentu. Walaupun demikian, perlu dipastikan lebih dahulu pengaruh pemanasan terhadap pertumbuhan tanaman. Dalam hal ini diharapkan bahwa tanaman dapat tetap tumbuh dengan baik pada perlakuan pemanasan tetapi infestasi virus dapat ditekan. Jumlah eksplan yang tumbuh pada bawang merah 'Bima Curut' cenderung lebih banyak, hal tersebut menunjukkan bahwa kultivar tersebut lebih toleran terhadap perlakuan pemanasan dibandingkan dengan bawang merah 'Sumenep'.

Hasil penelitian lebih lanjut menunjukkan bahwa pertumbuhan eksplan dengan perlakuan pemanasan pada suhu $50{ }^{\circ} \mathrm{C}$ menunjukkan hasil yang lebih baik dibandingkan dengan perlakuan pemanasan pada suhu $45{ }^{\circ} \mathrm{C}$. Hal ini karena perlakuan pemanasan yang diikuti dengan kultur meristem mampu mengembalikan potensi pertumbuhan planlet yang terganggu akibat keberadaan virus pada jaringan tanaman. Hasil penelitian Sulistio et al. (2015); Supenti dan Marlina (2011) menyatakan bahwa pertumbuhan planlet dengan perlakuan termoterapi selama tiga minggu yang diikuti dengan kultur meristem mampu mengembalikan potensi pertumbuhan planlet yang terganggu akibat keberadaan virus pada jaringan tanaman.

Pemanfaatan termoterapi untuk menekan infeksi virus telah dilaporkan pada berbagai jenis tanaman dan virus yang berbeda. Perlakuan pemanasan yang dikombinasikan dengan kultur jaringan pada bawang merah dapat mengeliminasi SLV dan OYDV (Fletcher et al. 2010). Lebih lanjut, penerapan metode kombinasi termoterapi pemanasan dan kultur meristem dilakukan untuk mengurangi tingkat kesulitan aplikasi. Metode kombinasi ini dilaporkan lebih efektif untuk mengeliminasi beberapa jenis virus dibandingkan dengan metode tunggal, yaitu kultur meristem atau termoterapi.

Nasution et al. (2017) menguraikan bahwa perlakuan termoterapi pada bawang putih memberikan pengaruh nyata terhadap persentase hidup eksplan. Perlakuan suhu terlalu tinggi berpengaruh negatif terhadap pertumbuhan eksplan. Eliminasi menggunakan metode elektroterapi pada berbagai tingkat arus listrik memperlihatkan tidak berpengaruh 
nyata terhadap persentase tanaman bebas virus. Perlakuan suhu $33^{\circ} \mathrm{C}$ mampu menghasilkan tanaman bebas OYDV pada kultivar Lumbu hijau hingga $60 \%$ dan kultivar Sangga Sembalun $40 \%$. Pada tanaman nilam kultur meristem apikal berhasil mengeliminasi virus sebanyak 33.3-99.9\% (Noveriza et al. 2012). Perendaman setek batang nilam menggunakan air panas pada suhu $50-60{ }^{\circ} \mathrm{C}$ selama 10 30 menit tidak dapat mengeliminasi Potyvirus.

Perlakuan pemanasan dalam inkubator di kondisi hari panjang pada suhu $38-40{ }^{\circ} \mathrm{C}$ selama 3 minggu yang diikuti kultur meristem dapat membebaskan 100\% plantlet krisan dari infeksi Chrysanthemum Virus-B (CVB) (Budiarto et al. 2008). Perlakuan pemanasan umbi bawang merah pada suhu $45{ }^{\circ} \mathrm{C}$ selama 45 menit mampu menekan insidensi penyakit sebanyak $64.35 \%$ dan berpengaruh meningkatkan produksi tanaman bawang merah sebesar 55-71\% (Harti et al. 2018). Dapat disimpulkan bahwa sebagian besar umbi bawang merah yang beredar di lapangan dan digunakan sebagai sumber benih sudah terinfeksi oleh beberapa jenis virus (OYDV, SLV, dan GCLV). Upaya untuk memperoleh umbi bebas virus sebagai benih sehat dapat dilakukan melalui kombinasi perlakuan suhu dan kultur jaringan. Perlakuan pemanasan pada suhu $45{ }^{\circ} \mathrm{C}$ selama 15 menit dapat mengeliminasi Potyvirus dan Carlavirus sampai $100 \%$ pada bawang merah 'Bima Curut'. Perlakuan air panas pada suhu $50{ }^{\circ} \mathrm{C}$ selama 15 menit dapat mengeliminasi Potyvirus sebesar 100\% tetapi hanya dapat menekan Carlavirus sebesar $33.33 \%$ pada bawang merah 'Sumenep'. Hasil ini mengindikasikan bahwa perlakuan yang terbaik untuk menekan infeksi virus dapat berbeda untuk setiap kultivar bawang merah.

\section{UCAPAN TERIMA KASIH}

Penelitian didanai oleh Badan Penelitian dan Pengembangan Pertanian, Proyek kerjasama Institut Pertanian Bogor (IPB) dan Australian Centre for International Agricultural Research (ACIAR Project HORT-2009-056) dan Pusat Kajian Hortikultura Tropika, IPB.

\section{DAFTAR PUSTAKA}

Almaarri K, Massa R, Albiski F. 2012. Evaluation of some therapies and meristem culture to eliminate Potato Y Potyvirus from infected potato plants. Plant Biotechnology. 29:237-243. DOI: https://doi.org/10.5511/ plantbiotechnology.12.0215a.

Anggraini S, Hidayat SH, 2014. Sensitivitas metode serologi dan polymerase chain reaction untuk mendeteksi Bean common mosaic potyvirus pada kacang panjang. J Fitopatol Indones. 10(1):17-22. DOI: https://doi.org/10.14692/jfi.10.1.17.

Budiarto K, Y. Sulyo, IB. Rahardjo, D. Pramanik. 2008. Pengaruh durasi pemanasan terhadap keberadaan Chrysanthemum Virus-B pada tiga varietas krisan terinfeksi. J Hort. 18(2):185-192.

Budiono DP. 2004. Multiplikasi in vitro tunas bawang merah (Allium ascalonicum L.) pada berbagai taraf konsentrasi air kelapa. J Agro. 8(2):75-80.

Doyle JJ, Doyle JJ. 1990. Isolation of plant DNA from fresh tissue. Focus. 12:13-15. DOI: https://doi.org/10.2307/2419362.

Duriat AS. 1990. Inventarization of pest and diseases on lowland vegetable in Madura, Bali dan Lombok. Bul Penel Hort. edisi khusus. 18:119-130.

Duriat AS, Sukarna E. 1990. Deteksi penyakit virus pada klon bawang merah. Bul Penel Hort. edisi khusus. 18:146-150.

Fajaro Thor VM, Nishijima M, Buso JA, Torres AC, Avila AC, Resende RO. 2001. Garlic viral complex: identification of Potyviruses and Carlavirus in Central Brazil [Internet]. Fito Brazil 26(3); [diunduh 2011 Feb 6]. Tersedia pada: http:// www. Scielo.briscielo. php?pid=S0100-41582001000300007 script $=$ sci arttext. DOI: https://doi. org/10.1590/S0100-41582001000300007.

Fletcher PJ, Fletcher JD, Lewthwaite SL. 2010. In vitro elimination of onion yellow dwarf and shallot latent viruses in shallots (Allium cepa var. ascalonicum L.). N Z J Crop Hortic Sci. 26(1):23-26. DOI: https:// doi.org/10.1080/01140671.1998.9514035. 
Gunawan LW. 1992. Teknik Kultur Jaringan Tumbuhan. PusatAntar Univ. Bioteknologi. Bogor (ID): Institut Pertanian Bogor.

Gunaeni N, Wulandari AW, Duriat AS, Muharam A. 2011. Insiden penyakit virus tular umbi pada tigabelas varietas bawang merah asal Jawa Barat dan Jawa Tengah. J Hort. 21(2):164-172. DOI: https://doi. org/10.21082/jhort.v21n2.2011.p164-172.

Hadidi A, Khetarpal RK, Koganezawa H. 1998. Plant Virus Diseases Control. St. Paul (US): APS Pr.

Harti H, Sobir, Wiyono S, Hidayat SH. 2018. Perlakuan air panas pada umbi bawang merah (Allium cepa var. ascalonicum) untuk menekan infeksi virus di lapangan. J Hortikultur Indones. 9(3):149-157. DOI: https://doi.org/10.29244/jhi.9.3.149-157.

Langeveld SA, Dore JM, Memelink J. 1991. Identification of potyviruses using the polymerase chain reaction with degenerate primers. J General Virology. 72:15311541. DOI: https://doi.org/10.1099/00221317-72-7-1531.

Murashige T, Skoog F. 1962. A revised medium for rapid growth and bio assays with tobacco tissue cultures. Physiologia plantarum. 15(3):473-497. DOI: https:// doi.org/10.1111/j.1399-3054.1962. tb08052.x.

Nasution SS, Dinarti D, Hidayat SH. 2017. Pengaruh elektroterapi dan termoterapi secara in vitro terhadap eliminasi Onion yellow dwarf virus. J Fitopatol Indones. 13(6):199-206. DOI: https://doi. org/10.14692/jfi.13.6.199.
Noveriza R, Suastika G, Hidayat SH, Kartosuwondo U. 2012. Eliminasi Potyvirus penyebab penyakit mosaik pada tanaman nilam dengan kultur meristem apikal dan perlakuan air panas pada setek batang. J. Littri. 18(3):107-114. DOI: https://doi.org/10.21082/jlittri. v18n3.2012.107-114.

Shahraeen N, Lesemann DE, Gholbi T. 2008. Survey for viruses infecting onion, garlic and leek crops in Iran. Eppo Bulletin. 38(1):131-135. DOI: https://doi. org/10.1111/j.1365-2338.2008.01198.x.

Sulistio M, Sulistyaningsih E, Subandiyah S. 2015. Elimination of shallot bulb viruses through heat treatment. Indo $\mathrm{J}$ Biotechnol. 20(2):133-140. DOI: https:// doi.org/10.22146/ijbiotech.24196.

Supenti, Marlina N. 2011. Teknik pembebasan virus pada tanaman krisan. Bul Tek Pert. 16(2):64-67.

Sutarya R, Van Vreden, Korlina E, Gunaeni N, Duriat AS. 1993. Survei virus bawang merah pada beberapa lokasi di Kabupaten Brebes, Jawa Tengah. Bul Penel Hort. 26(1):97-106.

Wulandari AW, Hidayat SH, Sobir. 2015. Deteksi virus pada bawang merah (Allium cepa var. ascalonicum) dengan metode $D o t$ Immuno Binding Assay. J Hort. 25(4):350356. DOI: https://doi.org/10.21082/jhort. v25n4.2015.p350-356. 